\title{
The Evaluation of 2013 Curriculum Implementation of Islamic Religious Education at School
}

\author{
arida Hanun ${ }^{1}$, Hayadin ${ }^{2}$, Iyoh Mastiyah ${ }^{3}$, Munawiroh ${ }^{4}$, Ummul Hidayati $^{5}$ \\ \{hanunjkt@gmail.com¹, hayadin006@gmail.com², mastiyah9@gmail.com ${ }^{3}$,mun.asrori@gmail.com ${ }^{4}$, \\ hidayatikuncoro@yahoo.com $\left.{ }^{5}\right\}$
}

Research \& Development and Training Agency, MoRA + $622131924509^{1,2,3,4,5}$

\begin{abstract}
The research of "Evaluation of 2013 Curriculum Implementation" aims to examine the implementation of the curriculum in Islamic religious subject in the school This research applied quantitative methods, survey. The survey is conducted in 11 provinces in Indonesia.. The results showed that the implementation of 2013 curriculum at Input Component goes not good (76.3\%) while Process Component goes well $(80 \%)$, and Output Component goes not good $(78.9 \%)$. The research raises several recommendations as follow:the The Ministry of Religious affair should strengthen the curriculum policy implications that have not maximum yet; encouraging efforts to fulfill the needs ofproviding appropriate learning facilities andenhancing the process of 2013 curriculum socializationfor teachers of Islamic religious in schools. Besides, intensifying support for the program through: the organization of intensive assistance to PAI teachers both administrative learning and teaching and learning activities, support KKG / MGMPs in activities to improve the teachers' competences through the provision of an adequate budget, and the Good Will of the government in the framework of monitoring the implementation of 2013 curriculum in integrated between religion and the Ministry of Education and Culture. Hence,this research is suggested their advanced research related to the extent of the effectiveness of support the implementation of the 2013 curriculum for teachers of Islamic religious in schools.
\end{abstract}

Keywords: Evaluation, Implementation, Curriculum, Islamic Religious Education

\section{Introduction}

2013 Curriculum is one of learning component. 2013 curriculum is a transformation of the development of the Education Unit Level Curriculum (Kurikulum Tingkat Satuan Pendidikan). The aim of this transformation is to improve the quality of education that is currently used today. By the improvement of curriculum, teaching and learning process will be run in a structured and in a systematic way to achieve the desired learning objectives. Curriculum development is very important in line with the advancement of science, technology, arts and culture, and changes in society. In addition, the curriculum should continue to change according to the needs of the community [1]. Only then, can the curriculum be an effective agent of change in the educational process [2].

In the framework of the implementation of 2013 Curriculum, the government issued a 
regulation on the implementation of curriculum as outlined in the Minister of Education and Culture No. 81A Year 2013, which states: "The implementation of the curriculum in primary schools /madrasah (SD/MI), junior high school/MTs (SMP/MTs), senior high school/madrasah aliyah (SMA/MA), and vocational schools/vocational madrasah aliyah (SMK / MAK) is done in stages starting in the academic year 2013/2014". "According to the above regulation, starting in the academic year 2013/2014, the government has imposed a new curriculum, namely 2013 curriculum (Ministry of Education and Culture No. 81A, Year 2013, chapter 1, about the Implementation of 2013 curriculum).

Nevertheless, by observing the development of 2013 curriculum implementation (K13), the government issued PERMENDIKBUD No.160/2014 on the re-enactment of 2006 curriculum, Article 1 in which states: "The units of primary schools and secondary schools in which implement 2013 curriculum in the first half academic year 2014-2015, will reimplement 2016 curriculum starting the second half academic year 2014-2015 until there is a provision of the Ministry to implement 2013 Curriculum.

In response to these policies, Director General of the Islamic Educational issuing a Circular Letter about the implementation of 2013 curriculum in Islamic Education will remain implemented in schools (Circular of the Director-General Number: SE / DJ.I / PP.00 / $143 / 2015$ on the implementation of 2013 Curriculum of PAI in Schools). This letter is enforced because there are three considerations as follow; First, in Article 3, paragraph 2 of Government Regulation (PP) No.55/2007 on the Religious Education and Religious Affairs stated that the Management of Religious Education implemented by the Ministry of Religious Affairs. Second, the Ministry of Religious Affairs, either through the Central and Regional (Regional MORA / Office MORA) has done a Technical Assistance (Technical Guidance) of 2013 Curriculum for PAI for most PAI teachers. In fact, for high school and vocational teachers of PAI already completed almost entire training materials, but a strengthening phase. Third, PAI excluding groups of subjects of national examination, https://www2.kemenag.go.id, retreived on January 1, 2015). Based on the Circular letter of the Director General, the Ministry of Religious affair continued to implement the 2013 curriculum, especially on the subjects of Islamic Religious Education (PAI) at schools.

Many schools have implemented 2013 curriculum. However, the government's policies encountered many obstacles at the level of implementation. This paper will present the evaluation results of 2013 curriculum implementation on Islamic religious education (PAI) in schools. This paper will discuss several topics included; 1) how do the input readiness of 2013 curriculum?, 2) How far the implementation of 2013 curriculum in the learning process?, 3) How do the impact of 2013 curriculum to learners, teachers and principals?, 4) What do the inhibiting and supporting factors of 2013 curriculum implementation?. In addition, the survey of this paper presents a measurable level of success in the implementation of the 2013 curriculum in junior high schools (SMP), which can be used as a material for policy formulation in education units (schools), the Ministry of Religion in Regencies/Cities, Ministry of Religious Affairs of the Province, Directorate of Islamic Religious Education, Research and Development Agency (Balitbang) and Training agency.

\section{Theory study}

There are several theories and previous research that can be used as supporting material for this study. There two key concepts of "curriculum implementation" and "evaluation". Curriculum implementation occupy a very important position in education. Implementation is an action to implement or realize what has been defined as a policy of a particular institution 
[3]. Many definitions of curriculum that is suggested by experts. In the beginning, the term 'curriculum' from the Greek 'curir', meaning 'runner' and 'curere' which means "the place to race". Kurikuluma simple understanding that educational programs contain subjects that must be taken by students in order to obtain a diploma [4].

Olivia defines curriculum as a program for all students' experiences under the direction of the school. The curriculum consists of a written plan that describes the scope of a variety of desired learning experiences. Things to be underlined here is that the plan for the learning experiences.[5] Majid and Andayani explains the curriculum contains a set of plans that will contain the experience of the students under the guidance of teachers [6]. Furthermore, Wiles $\&$ Bondi revealed the curriculum is a set of desired objectives through process development and lead to learning experiences for students [7].

Juridical basis related to the implementation of 2013 curriculum included Government regulations concerning Law No.20/2003 on National Education System, Article 1, paragraph 19 stated that the curriculum is a set of plans and arrangements about the objectives, content, additional subjects as well as the means used to guide the organization of learning activities to achieve specific educational goals.

According to Curriculum Development Academic Manuscript [8], the implementation of curriculum is an integral part of curriculum development and a follow-up of the curriculum construction documents. Two major activities in the implementation of the curriculum is to determine an implementation strategy and implementation of curriculum. Implementation of the curriculum on SD / MI, SMP / MTs, SMA / MA, and SMK /MAK is using the guidelines of the curriculum that includes: a) Guideline for the Management Unit Level Curriculum; b) Guidelines for Local Content Development; c) Guidelines for Extracurricular Activities; d) General Guidelines for Learning; and e) Guidelines for Curriculum Evaluation.

Practically, the implementation of the curriculum is a joint effort between the Government and the provincial government and local government.[9] In addition, implementation of the curriculum in primary schools/madrasah (SD / MI), junior/MTs (SMP / MTs), high school / madrasah aliyah (SMA/MA), and vocational schools/vocational madrasah aliyah (SMK/MAK) is done in stages starting in the academic year 2013/2014 (Regulation of the Minister of Education and Culture, No.81A/2013).

Moreover, the experts have developed several models of program evaluation as guidance in the implementation of the program evaluation. CIPP Model is a model of evaluation which saw the program being evaluated as a system. In other words, it is a series of whole four components. Nonetheless, according Stufflebeam, an evaluator in practice do not have to use the whole evaluation models. The uniqueness in these models is the evaluation of each type of decision-making related to the device and operation of a program.[10] CIPP is an abbreviation of four words, namely; 1) context evaluations, 2) input evaluation, 3) process evaluation, 4) product evaluation.

In addition to the previous studies, Abdillah in which conducted a curriculum evaluation at SMPN Puger, concluded the implementation of the 2013 curriculum has run well but not all implementation. In addition, training that is organized by the government, schools and MGMPs is helpful for PAI teachers to implement 2013 curriculum [11].

Other previous research has been conducted by Masruroh [12] entitled "Implementasi kurikulum 2013 pada mata pelajaran PAI di SMN 1 Karanganyar" has revealed that there were still constraints in implementing 2013 Curriculum in SMPN 1 Karanganyar as follow: 1) not the entire PAI textbook has distributed PAI; 2) frequent alternation of government regulation; 3) lack of visual aid facilities, for instance LCD, for learning activities so that the teacher should choose the appropriate method for implementing teaching adn learning 
activities; 4) less extensive mosque for Dhuhr prayer and Friday prayer activities at which should be scheduled in rotation; 5) unbalance learning activities of students, especially 7 th grade students. Moreover, (Mualimin, 2012) has conducted a research entitled "Implementasi Kurikulum Pendidikan Agama Islam (PAI) di SMP Negeri 1 RSBI Kota Magelang”. The results showed that inhibiting factors of curriculum implementation process have resulted the implementation became less smoothly. These factors are; 1) lack of learning time, 2) student input (at the beginning of the first year) are not equal in Islamic knowledge and reading and writing the Qur 'an, 3) changeable government policies.

\section{Methodology}

This research has conducted by using a survey method with quantitative approach in 2018. The collected data has described by using tables and graphics. The locations of this research were conducted at public schools and private schools of SMP scattered in 11 provinces, namely North Sumatra, South Sumatra, Riau, Jakarta, Banten, West Java, Central Java, East Java, West Kalimantan, South Sulawesi, East Nusa Tenggara.

Sampling technique of this research was using random sampling. Target population of this survey is the entire education units of public and private school of SMP throughout Indonesia (37741 institutions). Inaccessibility population was the number of SMPs in 11 provinces and sampling framework was 24.314 institutions. Error margin of $+/-7 \%$ set sample size of about 197 schools. The next step in a manner proportional set the amount of the providers on the terms of the status of the domestic / private in each province were selected based on the proportion of the population. Furthermore, with a purposive been SMPN and SMPS in the capital of each province.

The data collection is done by questionnaires and interview guidelines. Questionnaires used to collect data on the respondents as many as 426 teachers, learners as many as 1184 people, and supervisors as much as 2 per province with a total of 23 people and 11 Kasi PAIS MORA city. While the data analysis using descriptive statistical techniques through presentation of data obtained from the dissemination of the questionnaire in the form of tables or graphs. To determine the category in the achievement of the results of the data collection, used analysis of scores ideal (Sudjana, 2002: 56), ie the ratio of the average score by the maximum score. By categorizing the value achievement data collection as follows: a) Very good (90.00 to 100.00), Good (80.00 to 89.00), Fair (65.00 to 79.00), less (55, 00 to 64.00), and very less $(\leq 55.00)$.

\section{Results and discussion}

\subsection{Context component}

Juridical foundations related to the implementation of 2013 curriculum, namely: First, the Constitution of the Republic of Indonesia, Year 1945 related to Pancasila as the basic ideology of Pancasila. Second, law No.20/2003 about National Education System. Third, government regulation No.19/2005 about Standard of National Education. Fourth, the Minister of Education and Culture No. 81A Year 2013, which states: "The implementation of the curriculum in primary schools /madrasah (SD/MI), junior high school/MTs (SMP/MTs), senior high school/madrasah aliyah (SMA/MA), and vocational schools/vocational madrasah aliyah (SMK / MAK) is done in stages starting in the academic year 2013/2014”. According to the above regulation, starting in the academic year 2013/2014, the government has imposed a 
new curriculum, namely 2013 curriculum (Ministry of Education and Culture No. 81A, Year 2013, chapter 1, about the Implementation of 2013 curriculum).

Peraturan Menteri Pendidikan dan Kebudayaan No.160/2014 on the reenactment of 2006 curriculum, Article 1 in which states: "The units of primary schools and secondary schools in which implement 2013 curriculum in the first half academic year 2014-2015, will re-implement 2016 curriculum starting the second half academic year 2014-2015 until there is a provision of the Ministry to implement 2013 Curriculum." Circular of the DirectorGeneral Number: SE/DJ.I/PP.00/143/2015 on the implementation of 2013 Curriculum of PAI in Schools Director General of the Islamic Educational issuing a Circular on the implementation of Islamic Education K-13 to remain implemented in schools, because there are three considerations, namely; The first, in Article 3, paragraph 2 of Government Regulation (PP) No.55/2007 on the Religious Education and Religious Affairs stated that the Management of Religious Education implemented by the Ministry of Religious Affairs.

Second, Ministry of Religious Affairs, either through the Central and Regional (Regional MORA) has done a Technical Assistance (Technical Guidance) of 2013 Curriculum for PAI for most PAI teachers. In fact, for high school and vocational teachers of PAI already completed almost entire training materials, but a strengthening phase. Third, PAI excluding groups of subjects of national examination but a group of school exams, so that the implementation and assessment of maple PAI depending on the policy of each educational unit.

\subsection{Input component}

Research result, done by the Center for Religion and Religious Education revealed the presence of multiple input components of the implementation of the overall 2013 curriculum was not run well. The graph below shows the input component of the implementation of the K-13 as a whole was not run optimally. Aspects of the availability of devices and aspects of teachers have good understanding of the condition. While aspects of HR training of teachers already in good condition.

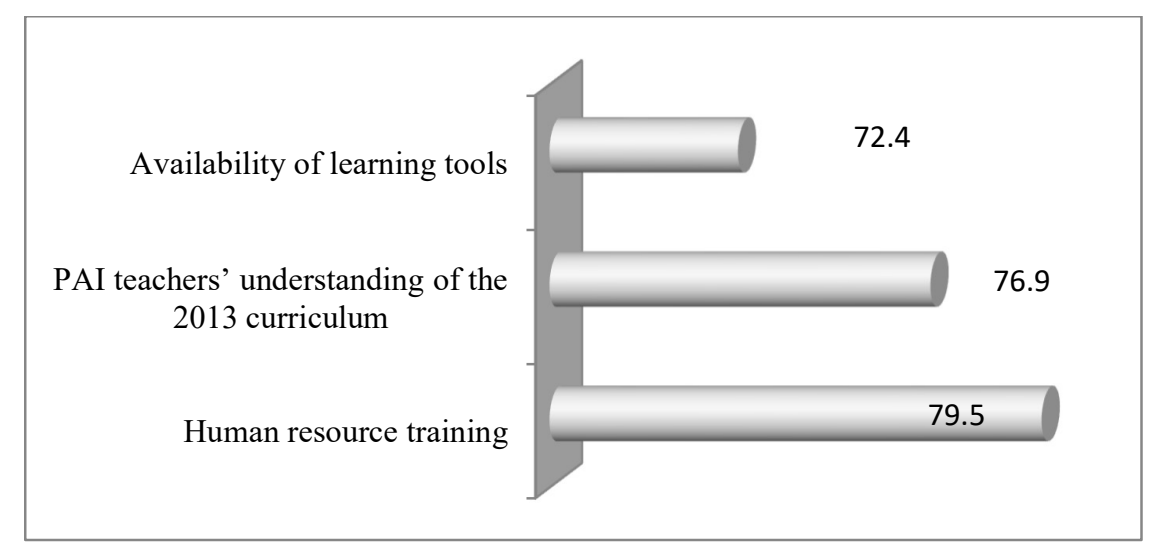

Fig. 1. Input component. 
The study also found that in the aspect of K-13 availability, there were several indicators that was not in good condition, namely RPP availability, availability of teachers' manual book, and students' textbook, the availability of 2013 curriculum guidelines, students' read able books, completed students' book, composing RPP, the preparation of lesson plans on the terms of the criteria that has been set.

Related aspects of the training curriculum of 2013, there are indicators that have not been in good condition including the availability of books in training, increase training time, the use of props that are relevant, maximizing the provision of the concept of authentic assessment, conveys the material professionals, training methods are qualified, a clear picture in PBM appropriate $\mathrm{K}-13$, and the increasing mastery of the material by the trainer. Data shows the implementation aspects of the training are still some things that need to be improved so that the results of the training curriculum in 2013 could be optimal among governments need to complement the availability of books, increased training time, complete the props. In addition, teachers should also be taught better in making authentic assessments.

In addition, aspects of teachers' understanding was also not good, especially in delivering spiritual competence, daily assessment, learning assessment, student guidance, understanding of self-assessment, teachers' manuals, authentic assessment, teacher assessment, and teachers' understanding based portfolios. All indicators have not been in the good categories. Ministry religion should pay more attention to the availability of the entire device of 2013 curriculum as aspects of the device influences the smoothness of the learning process of Islamic religious education in the classroom. If the process of learning in the classroom with 2013 curriculum was not optimal in doing the learning outcomes of Islamic religious education would not be maximum. Therefore, to improve the implementation of 2013 curriculum, teachers should discuss with their colleagues in developing an effective curriculum [14].

In terms of teachers' understanding, the data showed that there were eight indicators that need to be improved. For example, teachers' understanding of the student book and teacher manual is identified by teachers for teachers who do not understand the Islamic religious education textbooks will have an impact on knowledge transfer fluency. Likewise with teachers' understanding of the various types of assessment are all very important to understand by the teacher. Incorrect assessment procedure would lead to inaccurate assessments. Religious ministry needs more training curriculum how to make an assessment by 2013. A lack of understanding of PAI teachers as Mr. Arif acknowledged that the problem of PAI teachers among other difficulties in implementing the learning [15].

\subsection{Process component}

Furthermore, the findings related to the components of the process of 2013 curriculum implementation showed good in all aspects of the process component. 


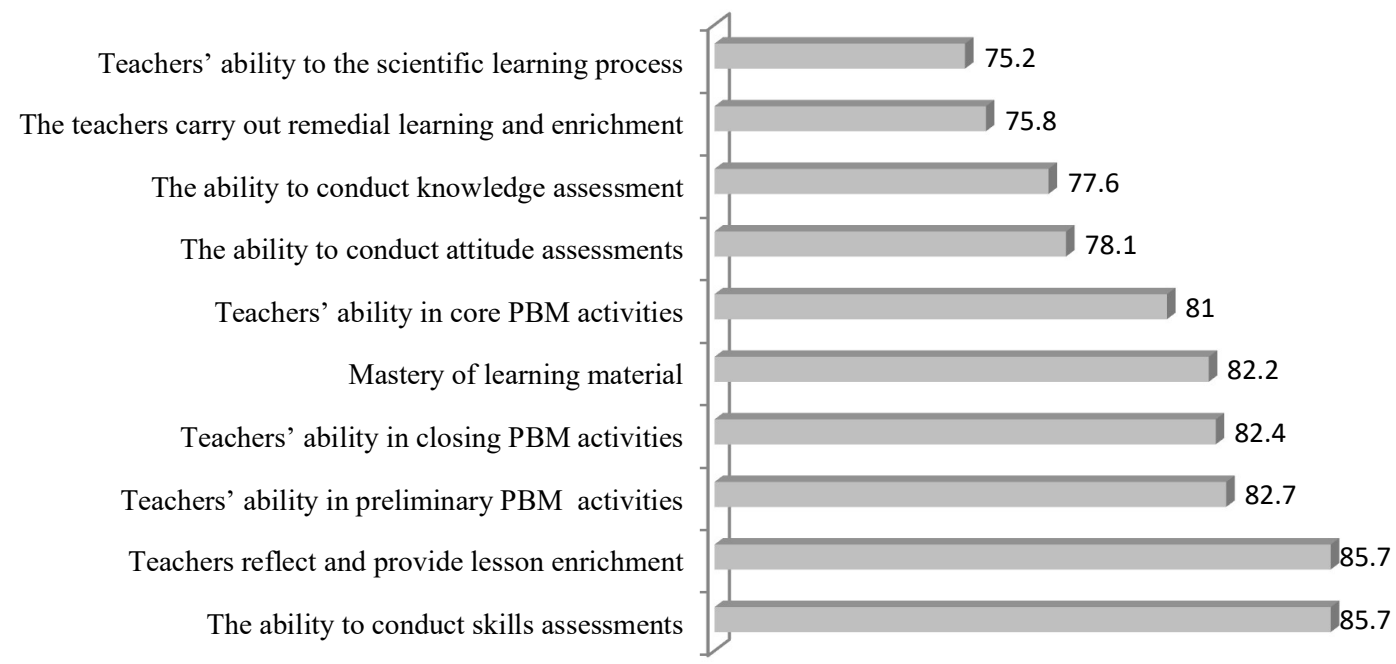

Fig. 2. Process component.

In the graph above showed the components already in a good position but there were still some aspects that needed to be improved, namely the ability of teachers to the learning process and the ability of teachers in remedial scientific implementation and enrichment learning has not gone well. Additionally, aspects of assessment need to be improved, especially in knowledge and attitude indicators because it was not in good condition. The results of this study found that teachers still weak in mastering scientific learning process. Scientific learning curriculum was novel in 2013 curriculum. So that many teachers were not maximized practically. The impact of scientific learning by teachers to the learning outcomes of students among learners was more productive, innovative, effected, and independent learning in the classroom [16]. Therefore, the government should be more focus on providing guidance for teachers to be more control of scientific learning. In addition, the ability of teachers to implement remedial and enrichment learning also needs to be improved. In accordance with Handler in which stated that teacher professional development is an important factor that contributes to the success of curriculum development and its implementation [17].

\subsection{Output component}

In the output component, there were aspects of religious practice by the student that needed more attention because the condition was not good, for instance, the activities of fardhu prayer, hasten ablution when azan, congregational prayers, read the quran every day, praying on time, attend Islamic lectures in schools, prayers in mosques, memorizing the quran, read the Quran with its meaning, read longer surah al-quran while prayer, fasting sunnah every Monday and Thursday. 


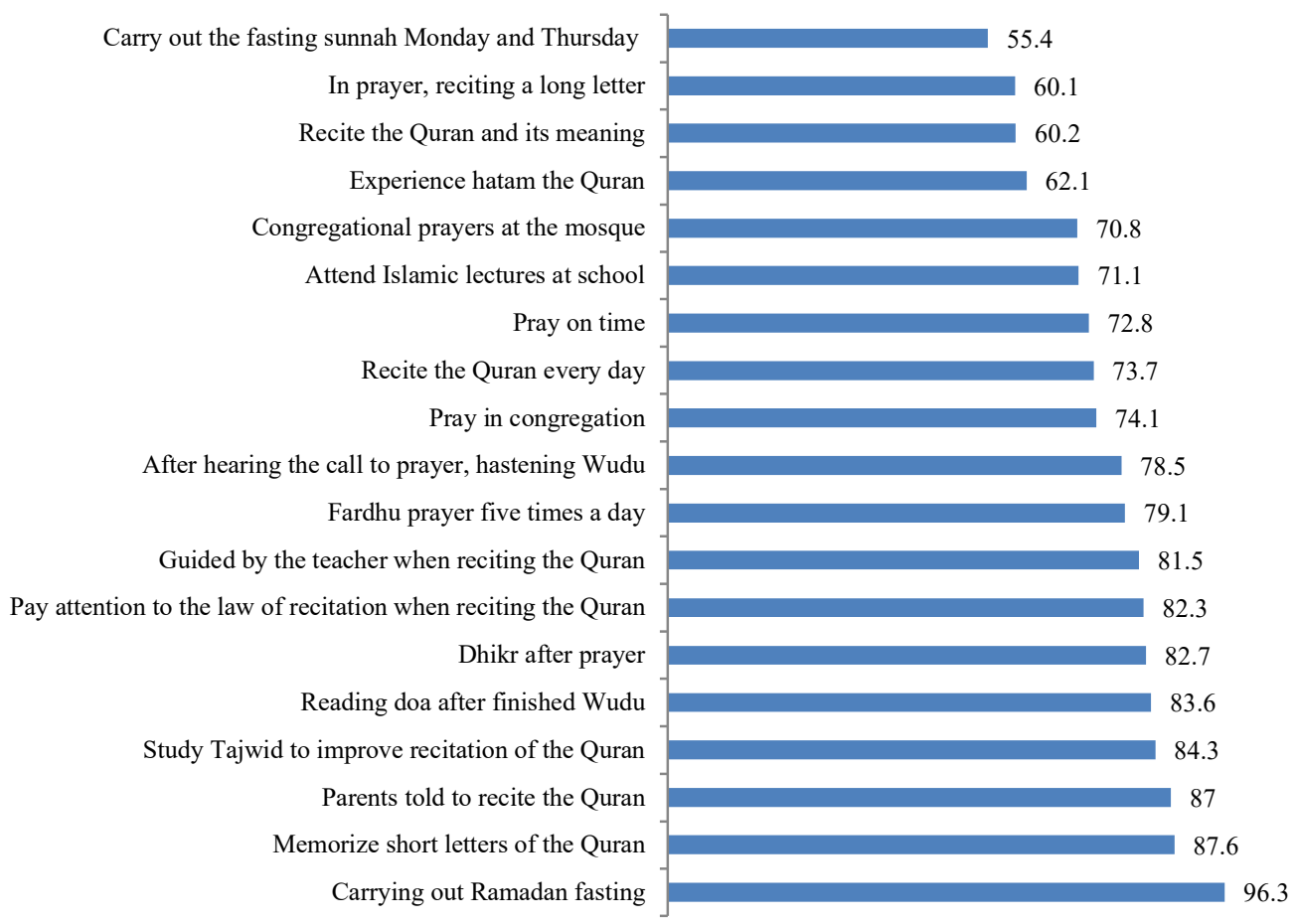

Fig. 3. Output component.

The data above showed that there were 11 dsstudents' practices of which needed to be improved on the implementation, namely, sunnah fasting, reading the Quran, prayer implementation. Integrated with a fun and exciting method as in the 2013 curriculum, teachers are expected to motivate learners to further improve the practice of the teachings of Islam. The role of the teacher in curriculum development is very important. The teacher provides a means for students to gain knowledge, skills, and develop attitudes. This can be done with the help of the curriculum provided. [18] On the other hand it is hoped that the government can design a curriculum that is relevant and responsive to better and in accordance with the needs of students.[19]

\section{Conclusion}

From this research, it concluded that there were still many aspects of the implementation of 2013 Curriculum that was not in optimal qualities. In terms of the Directorate of Islamic Education (PAIS) have optimized the 2013 curriculum implementation through monitoring. With the expected party monitoring activities, especially educational institutions and private junior high school is expected to know the implantation of 2013 Curriculum condition of which is ongoing process, so it can immediately make some repair before problems arise.

Supporting factors in which implemented 2013 Curriculum of Islamic Religious 
Education (PAI) subjects in the school were as follow; first, some schools have provided teacher textbooks and student textbooks. Second, some teachers have followed Bimtek K13 $P A I$ well held by MORA, Department of Education, KKG/MGMPs, and schools. Utilization of a variety of instructional media. PAI teacher was excited in participating training (Bimtek).

In the implementation of 2013 curriculum have supported by a variety of factors, but in practice was still encountered factors that hinder when implemented 2013 Curriculum for Islamic Religious Education (PAI) subjects in school included: PAI textbook was not yet fully available at the school for both private or public school. PAI teachers have not trained well in producing instructional media using information technology. Practically, 2013 implementation was not provided appropriate facilities, for instance, supporting notebook/laptop, projectors in the classroom of which supported the learning and teaching activities. In addition, some teachers have not followed Bimtek yet. In addition, the lack of a budget for the curriculum implementation. The amount of socialization curriculum teacher administration should be prepared while the teachers have the limited time because they have to teach 24 hours/ week. Lack of supporting PAI textbook has effected as well.

Furthermore, this research recommended several things as follow: First, Government Support. The government has implemented a policy of curriculum implementation in the decision of the Ministry of Education and Culture Regulation No.81A/2013 in which stated "The implementation of the curriculum at the school/Madrasah" and the Circular of the Director-General Number SE / DJ.I / PP.00 / 143/2015 on the implementation of 2013 Curriculum of PAI subject in Schools. However, the government's policy regarding the implementation of the curriculum in 2013 until now in the implementation stage was not run optimally. Therefore, for the implementation of 2013 curriculum policy can be applied maximally, it necessary to increasing budget to support 2013 curriculum implementation.

Second, Need Fulfillment. Ministry of Religious Affairs should provide the supporting policy in implementing 2013 curriculum through the curriculum need fulfillment. Ministry of Religious Affairs should also seek to assist in providing devices that should be met in Implementation of 2013 curriculum, namely the availability of student textbooks, teacher textbooks, human resource training, and mentoring. Third, Supporting program. the followup program in implementing 2013 curriculum can be done through several program as follow: 1) There should be periodic program related to implementation of 2013 curriculum for PAI subject especially in the district/city, 2) enable MGMP and KKG in self- development such as supporting KKG/MGMPs' program in the teacher development and improvement of teacher competences, and 3) the existence of Good Will of the PAIS Directorate of Religious Affairs regarding to curriculum implementation and its guidance and monitoring should be integrated between the Ministry of religious Affairs and the Ministry of Education and Culture

\section{REFERENCES}

[1] Alsubaie, M. 'Curriculum Development: Teacher Involvement in Curriculum Development', Journal of Education and Practice, 7(9). (2016)

[2] Glickman Et al, C. D. The Basic Guide To Supervision And Instructional Leadership. Boston: Pearson. (2013)

[3] Subandijah: Pengembangan dan Inovasi Kurikulum. Jakarta: Raja Grafindo. hh.56 (1996)

[4] Arifin: Konsep dan model pengembangan kurikulum. Bandung: PT. Remaja Rosdakarya Offset. hh. 2-3 (2011).

[5] Oliva: Developing the Curriculum. Boston: Pearson Education. hh. 19 (2005)

[6] Majid, A. and Andayani, D: Pendidikan Agam Islam Berbasis Kompetensi. Bandung: Pt Remaja. hh.15 (2006) 
[7] Wiles, J. W. and Bondi, J. C.: Curriculum Development: A Guide to Practice. Boston: Pearson. pp. 25 (2011)

[8] Kurikulum, P.: Naskah Akademik Pengembangan KurikulumNo Title. JAkarta: Kementerian Pendidikan dan Kebudayaan. pp. 87 (2011)

[9] Litbang, B. Kurikulum 2013: Rasional, Kerangka dasar, Struktur, Implementasi, dan Evaluasi Kurikulum. Jakarta: Kementerian Pendidikan dan Kebudayaan. pp. 54 (2013).

[10] James, Popham, W.: Educational Evaluation. New Jersey: Longman Higher Education. pp: 95 (2007)

[11] Abdillah, I. F.: Implementasi kurikulum 2013 pada mata pelajaran PAI di SMN 11 Puger. Fakultas Ilmu Tarbiyah dan Keguruan UIN Maulanan Malik Ibrahim. hh. 56 (2016).

[12] Masruroh, S.: Implementasi kurikulum 2013 pada mata pelajaran PAI di SMPN 1 dan SMPN 2 Karanganyar. Thesis Universitas Muhamadiyah Surakarta. hh. 85 (2018)

[13] Mualimin: M. Implementasi Kurikulum Pendidikan Agama Islam (PAI) di SMP Negeri 1 RSBI Kota Magelang. Thesis Program Pascasarjana IAIN Walisongo Semarang. hh. 112 (2012)

[14] Hidayat, Rukun and Damansyah 'The Development Of Character Education Curriculum For Elementary Student In West Sumatera', International Journal of Education and Research, 2(6). (2014)

[15] Hidayatulloh, A., Anam, W. and Fanani, Z. 'Problematka Dalam Pembelajaran PAI', Jurnal Edudeena, 1(2). (2017)

[16] Umiati: Penerapan pembelajaran saintifik dalam meningkatkan hasil belajar siswa pada mata peljaran PAI di SMPN 4 Kota Malang. Skripsi Jurusan PAI FITK UIN Malik Ibrahim Malang. hh. 89 (2015)

[17] Handler 'Teacher as curriculum leader: A consideration of the appropriateness of that role assignment to classroom-based practitioners', International Journal of Teacher Leadership, 3 (2). (2010)

[18] Jadhav, Sahebrao, M. and Patankar, P. S. 'Role Of Teachers' In Curriculum Development For Teacher Education', in For National conference on Challenges in Teacher Education, Physical Education and Sports: Teachers as curriculum developers. Kolhapur: Department of Education and Physical Education Mahavir Mahavidyalaya. (2013)

[19] Boyle, T. and Phelps, R. 'Pathways to Teaching: A Curriculum Innovation Enhancing Recognition of Students' Career Aspirations and Expectations: Redesigning Curriculum to Acknowledge Diversity', The International Journal Of Learning, 17 (2). (2010) 